\title{
Assessment of Initial Delivery of the Armor Captains' Career Course (Distance Learning)
}

\author{
William R. Sanders and Billy L. Burnside \\ U.S. Army Research Institute
}

\section{Armored Forces Research Unit Barbara A. Black, Chief}

U.S. Army Research Institute for the Behavioral and Social Sciences 5001 Eisenhower Avenue, Alexandria, Virginia 22333-5600

August 2001 